\title{
The effect of Instagram conspicuous consumptive behaviour on the intention to purchase luxury goods: A developing country's perspective
}

\begin{tabular}{|c|c|}
\hline \multicolumn{2}{|c|}{$\begin{array}{l}\text { Authors: } \\
\text { Ntsundeni Madzunya }^{1} \text { (D) } \\
\text { Kim Viljoen }^{1} \text { (D) } \\
\text { Liezel Cilliers }^{2} \text { (D) }\end{array}$} \\
\hline \multicolumn{2}{|c|}{$\begin{array}{l}\text { Affiliations: } \\
{ }^{1} \text { Department of Business } \\
\text { Management, Faculty of } \\
\text { Management and Commerce, } \\
\text { University of Fort Hare, East } \\
\text { London, South Africa }\end{array}$} \\
\hline \multicolumn{2}{|c|}{$\begin{array}{l}{ }^{2} \text { Department of Information } \\
\text { Systems, Faculty of } \\
\text { Management and Commerce, } \\
\text { University of Fort Hare, East } \\
\text { London, South Africa }\end{array}$} \\
\hline \multicolumn{2}{|c|}{$\begin{array}{l}\text { Corresponding author: } \\
\text { Liezel Cilliers, } \\
\text { liezelcilliers@yahoo.com }\end{array}$} \\
\hline \multicolumn{2}{|c|}{$\begin{array}{l}\text { Dates: } \\
\text { Received: } 03 \text { June } 2020 \\
\text { Accepted: } 22 \text { Nov. } 2020 \\
\text { Published: } 06 \text { Aug. } 2021\end{array}$} \\
\hline \multicolumn{2}{|c|}{$\begin{array}{l}\text { How to cite this article: } \\
\text { Madzunya, N., Viljoen, K. \& } \\
\text { Cilliers, L., 2021, 'The effect } \\
\text { of Instagram conspicuous } \\
\text { consumptive behaviour on } \\
\text { the intention to purchase } \\
\text { luxury goods: A developing } \\
\text { country's perspective', } \\
\text { South African Journal of } \\
\text { Information Management } \\
\text { 23(1), a1267. https://doi. } \\
\text { org/10.4102/sajim. } \\
\text { v23i1.1267 }\end{array}$} \\
\hline \multicolumn{2}{|c|}{$\begin{array}{l}\text { Copyright: } \\
\text { (C) 2021. The Authors } \\
\text { Licensee: AOSIS. This } \\
\text { is licensed under the } \\
\text { Creative Commons } \\
\text { Attribution License. }\end{array}$} \\
\hline \multicolumn{2}{|l|}{ Read online: } \\
\hline 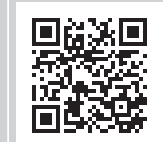 & $\begin{array}{l}\text { Scan this QR } \\
\text { code with your } \\
\text { smart phone or } \\
\text { mobile device } \\
\text { to read online. }\end{array}$ \\
\hline
\end{tabular}

Background: Social media has grown to such a large extent that it has become a primary source of information amongst consumers online. Consequently, South Africa has seen an exponential growth in the use of Instagram.

Objective: The study investigates the effect of Instagram conspicuous consumptive behaviour on the intention to purchase luxury goods.

Methodology: Data collected from 364 South African respondents through a quantitative survey demonstrated the extent to which Instagram affected conspicuous consumptive buying behaviours. The survey was distributed via social media and the results were analysed using structured equation modelling.

Results: The study revealed that although Instagram usage intensity effects conspicuous consumptive behaviour, electronic-word-of-mouth (eWOM) credibility does not. This is because respondents considered Instagram as a platform where users deliberately display the positive aspects of their lives as opposed to its objective state. Furthermore, the study revealed users on Instagram display high levels of conspicuous behaviour that they intend to transform into luxury purchases.

Conclusion: Results from the study contribute to luxury marketers and other stakeholders in creating social media strategies and policies whilst providing valuable insight in understanding online conspicuous behaviours.

Keywords: electronic-word-of-mouth (eWOM); purchase intention; Instagram; social media usage intensity; conspicuous consumption.

\section{Introduction}

Social media is born from the introduction of Web 2.0 technologies. Web 2.0 technologies describe sites that emphasise user-generated content, usability and interoperability (Thoumrungroje 2018). Web 2.0 technologies have enabled social media, such as the social networking site Facebook; the microblog, Twitter; and the photo sharing site, Instagram, to thrive. Social media incorporates a 'wide range of online word-of-mouth forums', including Facebook, Twitter, Instagram, LinkedIn and Snapchat (Erkan \& Evans 2016; Thoumrungroje 2018).

In South Africa, the internet has been embraced by South Africans, such that in 2018 more than $54 \%$ of the South African population had access to the internet. South Africa is seen to contribute to the growth of social media on a wide scale, reporting 23 million active social media accounts and a growth rate of 20\% (Patricios \& Goldstuck 2018). In 2018, Patricios and Goldstuck (2018) reported that Instagram had redefined the social landscape in South Africa with a 33\% growth rate, higher than any other social media platform. Instagram is characterised as an online, mobile photo-sharing, video-sharing and social networking site. Despite its considerable growth, limited academic research has been carried out regarding Instagram's influence on consumer behaviour. The popular site has long been labelled as a 'hotbed' for conspicuous behaviour (Thoumrungroje 2018).

The revolution of social media has altered the communication landscape significantly, consequently impacting marketing communications (Alves, Fernades \& Raposo 2016; Thoumrungroje 2018). The use of social media has influenced consumers' communication habits, consumption behaviour and attitudes (Kudeshia \& Kumar 2017; Tien, Rivas \& Liao 2018). Compared with traditional marketing and communication channels, social media holds the 
advantage of communication based on previously established networks (Hsu, Chih \& Liou 2016). This may be seen as more effective as individuals are seen to view usergenerated content, that they have previously seen communicated, as more credible than new ones (Erkan \& Evans 2016). The fundamental characteristic in social media is user-generated content; owing to this, users can carefully control their content by only sharing positive images about themselves amongst their network of acquaintances (Thoumrungroje 2014).

Consumers now have more choice than ever where to buy luxury good because of the exposure of social media marketing (Kaplan \& Haenlein 2010). The emergent communication structure of social media has seen consumers shift from passive participants to active creators and influencers in marketing causing a transfer of power directly to the consumers (Hsu et al. 2016; Tuten \& Solomon 2017). Consumers no longer rely on information pushed by marketers, rather they are able to critique information shared online to form their own opinion before purchasing or influencing the opinion of their peers of luxury brands (Bahtar \& Muda 2016; Erkan \& Evans 2016).

Wilcox and Stephen (2013) found that an individual with a higher esteem because of social media is likely to engage in impulsive and indulgent consumptive behaviour, such as excessive spending on conspicuous goods. Conspicuous goods are those that display wealth and status whilst satisfying an individual's need for prestige (Huang \& Wang 2018). Several authors state that social media can lead individuals to make irrational choices by increasing their expenditure on conspicuous goods, instead of confining themselves to basic necessities (Ismail, Nguyen \& Melewar 2018; Thoumrungroje 2014).

Social media allows a diverse range of factors to influence a consumer such as consumer characteristics, which includes the frequency and intensity of social media usage and peer interactions that affect a consumer's purchase decision (Taylor \& Strutton 2016). The interaction between consumers online is referred to as electronic-word-ofmouth (eWOM). Kudeshia and Kumar (2017) postulated that eWOM usually occurs within an existing social network, thus increasing the credibility and persuasive nature of eWOM.

The pervasiveness of conspicuous consumption in South Africa has been identified and previously studied, but its relation to the specific context of social media has not been explored (Bongazana 2014). However, with the growth of social media users in South Africa, it is imperative to understand how social media affects conspicuous behaviour and intention to purchase in the South African context. Existing research on conspicuous consumption primarily focuses on the growing group of middle- or upper-class urban residents with high social status and purchasing power in developed countries (Bongazana 2014; Huang \& Wang 2018).
This article, however, aims to study the pervasive use of social media among the growing segment of affluent consumers in South Africa. Thus, the present study investigates the effect of Instagram conspicuous consumptive behaviour on the intention to purchase luxury goods in a developing country perspective.

\section{Literature review}

The objective of this study was to examine the effect of Instagram on consumer conspicuous consumptive behaviour and consequently their intention to purchase luxury goods. The theoretical foundation of the study is based on Homans (1961) social exchange theory to propose that social exchange is a two-way communication activity that will either be rewarding or costly to an individual. Homans (1961) summarised the theory in stating that social exchange can involve an exchange of symbols, such as, approval and prestige. Individuals value relationships whose benefits enhance their social status (Faraj \& Johnson 2011). Social exchange theory aims to explain human interactions. The theory suggests that meaningful relationships are formed through subjective analysis of how the individuals benefit from the relationship (Surma 2015). Social exchange posits that relationships evolve over time into trusting, loyal and mutual commitments. For the purposes of the present study, individuals who find the exchange present in social media to be beneficial are more likely to engage in online communities. Social exchange online is also seen to influence conspicuous behaviour in individuals.

In accordance with the theory explained here and to answer the research objective, a conceptual framework that delineates the relationships amongst the key variables was developed to identify factors that predict conspicuous behaviour on Instagram: specifically, Instagram usage intensity and eWOM credibility. Figure 1 illustrates the conceptual framework of the study, whilst each part of the framework will be discussed here.

\section{Instagram usage intensity}

Traditional mass media, according to Gao and Feng (2016), allowed users to seek information, entertain themselves, interact with peers, express views and opinion, and engage in impression management. Social media intensity is defined as a social media user's level of activity and engagement with social media.

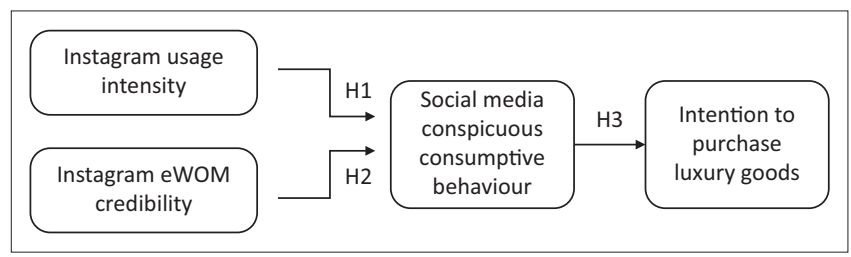

eWOM, electronic-word-of-mouth.

FIGURE 1: The conceptual model. 
Social media is rapidly becoming one of the most timeconsuming activities in a person's life. With the rapid growth mobile devices, interactions on social media are more common (Li, Park \& Park 2016). Instagram has become one of the largest social media platforms in the world, with an average of 1 billion active users. Thoumrungroje (2014) suggested that intensity of the use of social media has a dynamic influence on consumer consumptive behaviour. South African Instagram users are no different as Instagram has redefined the social media landscape over the past 3 years, obtaining a growth rate of 32\% since 2017 (Patricios \& Goldstuck 2018). Instagram has over 3.6 million users in South Africa.

In addition, consumers who spend more time on social media gain more product knowledge (Ismail et al. 2018; Thoumrungroje 2018). Intense social media users learn from peers about consumption values, products, brands and lifestyles that are acceptable in their social and aspiration groups (Chu, Windels \& Kamal 2016). Thus, based on a review of the literature, the following hypothesis is proposed:

H1: Instagram usage intensity does not have a significantly positive effect on conspicuous consumptive behaviour.

\section{Electronic-word-of-mouth credibility}

The various platforms of social media such as blogs, social networking sites, forums and review sites facilitate the exchange of information between consumers. Although eWOM is a result of word-of-mouth (WOM), the two communication processes possess significant differences. Firstly, unparalleled scalability and speed of diffusion are present in eWOM that are not found in the traditional WOM (Cheung \& Thadani 2012). The WOM communication involves small groups sharing information synchronously; eWOM, on the other hand, allows a multiway of exchanges of information amongst consumers asynchronously (Tien et al. 2018).

Secondly, the ability of eWOM communications to be archived increases the level of persistence and accessibility of information online as opposed to WOM (Cheung \& Thadani 2012). Lastly, the issue of credibility is vastly different in the traditional WOM; the sender is usually previously known by the receiver. However, with eWOM, the application's facilitation of the communication process usually eliminates the receiver's ability to judge the credibility of the sender and/or message (Cheung \& Thadani 2012). However, Erkan and Evans (2016) posited a contradictory perspective indicating that eWOM usually occurs within an existing social network, thus increasing the credibility and persuasive nature of eWOM.

Source credibility is defined as the perception of trustworthiness, expertise and the trust a user has towards his or her social network (Djafarova \& Rushworth 2017; Tien et al. 2018). Hsu et al. (2016) found that credibility is built as a result of the expertise given by the source and the trustworthiness regarding the objective description and sincerity of the message sent. Previous research has indicated the direct positive correlation between consumer's attitudes and information provided by highly credible sources. As a result, individuals are more likely to adopt the viewpoint of their source (Cheung \& Thadani 2012; Kudeshia \& Kumar 2017). Conversely, Sussman and Siegel (2003) suggested that source credibility will prejudice the information processing through the change of an individual's inclination to suspect or support the given information. Similarly, Pornpitakpan (2004) suggested several variables, such as information-related factors and the affecting attitudes of individuals, are present in the interaction and may explain the adoption of information from a credible source.

Credibility of eWOM, most importantly, has been linked with consumption of conspicuous goods (Ismail et al. 2018; Thoumrungroje 2014). Social media has created a structure where consumers tend to trust peers more than companies; this structure brings new implications and pushes marketers to change the way they communicate and interact with consumers (Deghani \& Tumer 2015; Tien et al. 2018). Individuals on social media feel the need to gain social acceptance of online peers and the need for a good 'social image'; social media is, therefore, likely to reinforce conspicuous consumption (Duan \& Dholakia 2017; Jain, Khan \& Mishra 2015; Thoumrungroje 2014). Users in social media choose to only share positive information about themselves, favourable images and prestige that give positive feedback to other users (Duan \& Dholakia 2017). Moreover, the eWOM concerning the purchase of luxurious products from people who are connected is more likely to result in consumers making irrational choices by increasing the expenditure on conspicuous goods (Ismail et al. 2018; Jain et al. 2015; Thoumrungroje 2018). Therefore, the second hypothesis of the study is proposed as follows:

H2: Instagram eWOM credibility does not have a significantly positive effect on conspicuous consumptive behaviour.

\section{Conspicuous consumption on Instagram}

Conspicuous consumption is a behavioural pattern where consumers ostentatiously obtain, use and display goods and services to gain social status, more than to meet functional needs (Hammerl \& Kradischnig 2018). Social media has significantly altered the traditional conspicuous consumption theory, as all consumption now has the possibility of becoming conspicuous consumption based on how individuals make use of social media (Yenicioglu \& Christodoulides 2014). The continuous, real-time communication channels that online platforms present result in constant displays by consumers. The social media environment allows consumers to engage in typical conspicuous consumptive behaviour on a larger social network scale (Thoumrungroje 2014).

As a result of Instagram placing large emphasis on visual character, it creates a fertile environment to promote conspicuous displays. The advent of social media has created a new platform for materialistic displays, and users use the platform to share their purchases and intentions (Ho, Shin \& Lwin 2017; Thoumrungroje 2018). Hammerl and Kradischnig 
(2018) posited that although individuals have chosen to display their wealth differently over the years, the objective of gaining status has remained unaffected. Sharing on social media is used by consumers as a means to display their social status (Chu et al. 2016; Jain et al. 2015). Jain et al. (2015) found that youth use social media to promote individual autonomy and shared interests online, in a manner that shows their perceived wealth. Luxury products online are used and purchased by individuals to signal their status and wealth (Taylor \& Strutton 2016; Thoumrungroje 2018). Social media has widened the consumer's access to social networks, a consequence of which is that consumers now have access to more commercial markets (Huang \& Wang 2018). Emerging markets such as South Africa are now exposed to global luxury markets:

H3: Instagram conspicuous consumptive behaviour does not have a significantly positive influence on intention to purchase luxury goods.

\section{Intention to purchase}

Purchase intention is defined as the probability that a consumer will be willing to purchase a product or services. Purchase intention is a concept used to predict consumer behaviour. Schiffman and Wisenblit (2015) stated that positive purchase intention not only indicates the likelihood of actual purchase but also a positive commitment or loyalty towards brands and products. Studies have corroborated that if a consumer has received positive information through their online social media, it significantly influences their purchase intentions, and moreover their willingness to pay a premium for goods (Kudeshia \& Kumar 2017). Paying premium value for goods has been widely linked with luxury consumption and conspicuousness.

According to Sher and Lee (2009), purchased intention is the most prevalent variable resulting from online social communications. Negative or positive online consumer information has significant impact on consumer attitudes towards brands and products. Recommendations by online networks are positively related with purchase intentions and can directly affect and impact consumer purchase decisions (Chang \& Chin 2010). Both online quality and online quantity were found to have positive influences on customers' purchase intentions (Li et al. 2016). Social media purchase decisions are influenced by interactions online, the impact of which affects brands and marketers (Ismail et al. 2018).

\section{Methodology}

Research suggests that the utilisation of social media in emerging markets is steadily on the rise (Patricios \& Goldstuck 2018). It is for this reason that South Africa was chosen as a context of this study. South Africa's double digit growth rate, daily internet usage and reliance on social media make the country a great representative for emerging markets with similar characteristics. Patricios and Golstuck (2018) stated that Instagram is amongst the fastest growing social media platforms in South Africa.
In order to test the hypothesised relationships amongst variables in the proposed research model, a quantitative survey was conducted. This type of research lends itself to the positivism paradigm, which states that only objective, observable facts can be the basis for science. Quantitative research provided a formalised data structure where the study could measure what people think from a statistical and numerical point of view (Malhotra 2014). This was ideal as the response options were predetermined by the researcher, thereby allowing the numerical data to be collected and analysed (Wiid \& Diggines 2015). In addition, this approach was chosen as the intention of the study is to reach a substantial number of respondents, collect data and develop summaries about the sample drawn, rather than exploring and monitoring data

Data for the study were collected using snowball sampling. Snowball sampling is an approach characterised by the referrals (Wiid \& Diggines 2015). This study required users from Instagram and Facebook specifically, and therefore, this technique was deemed more appropriate. An online survey was conducted to collect primary data, through the use of a questionnaire developed from previous studies (Chung \& Fisher 2001; Ellison, Steinfield \& Lampe 2007; Hung et al. 2011; Smith \& Vogt 1995). The questionnaire was administered online through the Survey Monkey platform. Online surveys are easy to administer, are inexpensive and can reach a wider geographical audience in a shorter period of time. A link with a set of questions was sent to respondents through various social media platforms and emails, which consumers would use to access the questionnaire. Respondents were encouraged to forward the link to the questionnaire as a means to generate a larger response rate. Making use of the Raosoft calculator, a sample of 377 respondents was suggested, as a generalisable result can be obtained with that sample size (confidence level 95\% and margin of error 5\%). A larger sample size was not considered to have any meaningful impact on the results of the study (Wiid \& Diggines 2015). A final usable sample of 364 respondents was included in the data collection of this study while ethical clearance was granted from the University Research Ethics Committee.

\section{Measures and scale assessment}

The design of the survey adopted a multi-item approach; each construct was measured by several items to improve validity and reliability. All items in the survey were measured by a five-point Likert-scale, ranging from strongly disagree (1) to strongly agree (5). The constructs of the study were based on previous literature. Specifically, the Instagram usage intensity scale was adapted from Ellison et al. (2007). The Instagram eWOM credibility scale was assessed by adapting four items from Smith and Vogt (1995). The conspicuous consumption scale consisting of five items was adopted from Chung and Fisher (2001). Finally, the intention to purchase luxury goods scale was derived from Hung et al. (2011). 
In addition, the study tested the survey for validity and reliability. Factor loadings and Cronbach's alpha coefficients were the criteria used to determine the validity and reliability of the constructs, respectively. Table 1 provides a combined summary of validity and reliability analysis.

The Cronbach's alpha coefficient was used to assess if the measure of the scale was reliable and a Cronbach's alpha coefficient of more than 0.7 was considered significant for this study (Wiid \& Diggines 2015). All the constructs of the scale employed in this study computed a good degree of reliability and satisfactory evidence of construct validity.

\section{Ethical consideration}

The study received ethical clearance from the University of Fort Hare's Research Ethics Committee. Ethical Clearance Number: VIL151SMAD01.

\section{Results \\ Demographics}

The demographic characteristics provided in Table 2 indicate the results from 364 respondents. A total 196 of the responses were female and 168 were male (54\% vs. $46 \%$ ). Most of the sample consisted of respondents aged 25-34, indicated by their $43 \%$ response rate. Furthermore, the study revealed that $29 \%$ of respondents spent over $3 \mathrm{~h}$ on Instagram daily. This is consistent with current statistics depicting the generous growth of Instagram over the years (Patrcios \& Golstuck 2018).

TABLE 1: Summary of reliability and validity analysis.

\begin{tabular}{lccc}
\hline Construct & $\begin{array}{c}\text { Number of } \\
\text { items }\end{array}$ & $\begin{array}{c}\text { Cronbach's } \\
\text { alpha }\end{array}$ & $\begin{array}{c}\text { Range of factor } \\
\text { loadings }\end{array}$ \\
\hline Instagram usage intensity & 6 & 0.892 & $0.631-0.832$ \\
$\begin{array}{l}\text { Instagram eWOM credibility } \\
\begin{array}{l}\text { Instagram conspicuous } \\
\text { consumption }\end{array}\end{array}$ & 4 & 0.877 & $0.766-0.771$ \\
$\begin{array}{l}\text { Instagram intention to purchase } \\
\text { lntion }\end{array}$ & 4 & 0.931 & $0.821-0.887$ \\
\hline
\end{tabular}

eWOM, electronic-word-of-mouth.

TABLE 2: Demographic information of respondents.

\begin{tabular}{lcc}
\hline Measure & Frequency & $\%$ \\
\hline Gender & 196 & 54 \\
Female & 168 & 46 \\
Male & & \\
Age (years) & 117 & 32.1 \\
$18-24$ & 159 & 43.7 \\
$25-34$ & 59 & 16.2 \\
$35-44$ & 24 & 6.6 \\
$45-54$ & 4 & 1.1 \\
$55-64$ & 1 & 0.3 \\
$65+$ & & \\
Daily Instagram usage & 109 & 29 \\
30 min or less & 91 & 25 \\
30 min - $1 \mathrm{~h}$ & 76 & 21 \\
$1 \mathrm{~h}-2 \mathrm{~h}$ & 58 & 16 \\
$2 \mathrm{~h}-3 \mathrm{~h}$ & 33 & 9 \\
$3+\mathrm{h}$ & &
\end{tabular}

\section{Model analysis}

The hypotheses of this study were tested by means of structural equation modelling. The research model was tested using Statistical Package for the Social Sciences (SPSS) version 24 . The overall fit for both the measurement and structural models measured showed a $p$-value of 0.000 , which indicates significant models. Illustrated in Table 3 is a summary of the goodness-of-fit values.

Table 3 depicts the summary of the goodness-of-fit statistics for the structural model.

In an attempt to analyse the structural relationships between the variables in the empirical model, the structural model was used. Various fit indices were computed to measure the fitness of the model. A root mean square error of approximation (RMSEA) value of 0.053 reported for this study is statistically significant regarding its structural fit as it is above the accepted RMSEA of 0.05. The normed fit index (NFI) and non-normed fit index (NNFI) reported 0.970 and 0.985 , respectively, which is strong evidence of good fits for a structural model. The other reported statistics also proved to be a good fit for the structural model and were recorded as follows: parsimony normed fit index (PNFI) 0.840, comparative fit index (CFI) 0.987 , incremental fit index (IFI) 0.987 and relative fit index (RFI) 0.966 . These statistics were close to 1 , which indicates a good fit for the structural model. Therefore, it can be concluded that the model is significant and regarded as a good fit. Figure 2 provides the structural model for this study.

The maximum likelihood estimation method was employed to estimate the path coefficients of the structural model. These path coefficients explained the correlation strength between variables. The path parameters through estimation analysed the findings of the data collected and determined that only the Instagram usage intensity was strongly correlated to conspicuous consumptive behaviour. However, it also determined that Instagram eWOM credibility has a weak influence on Instagram conspicuous consumptive behaviour. Moreover, through estimation, the path parameters also determined the degree of influence, which conspicuous consumptive behaviour had no intention to

\begin{tabular}{lc} 
TABLE 3: Summary of goodness-of-fit values. & \\
\hline Fit index & Value \\
\hline Degrees of freedom & 148 \\
Normal theory weighted least squares chi-square* & 512.318 \\
Root mean square error of approximation (RMSEA) & 0.0534 \\
Chi-square corrected for non-normality* & 554.498 \\
90\% confidence interval for RMSEA & $0.0429 ; 0.0638$ \\
Normed fit index (NFI) & 0.97 \\
Non-normed fit index (NNFI) & 0.985 \\
Parsimony normed fit index (PNFI) & 0.84 \\
Comparative fit index (CFI) & 0.987 \\
Incremental fit index (IFI) & 0.987 \\
Relative fit index (RFI) & 0.966 \\
\hline
\end{tabular}

$*, p=0.000$. 


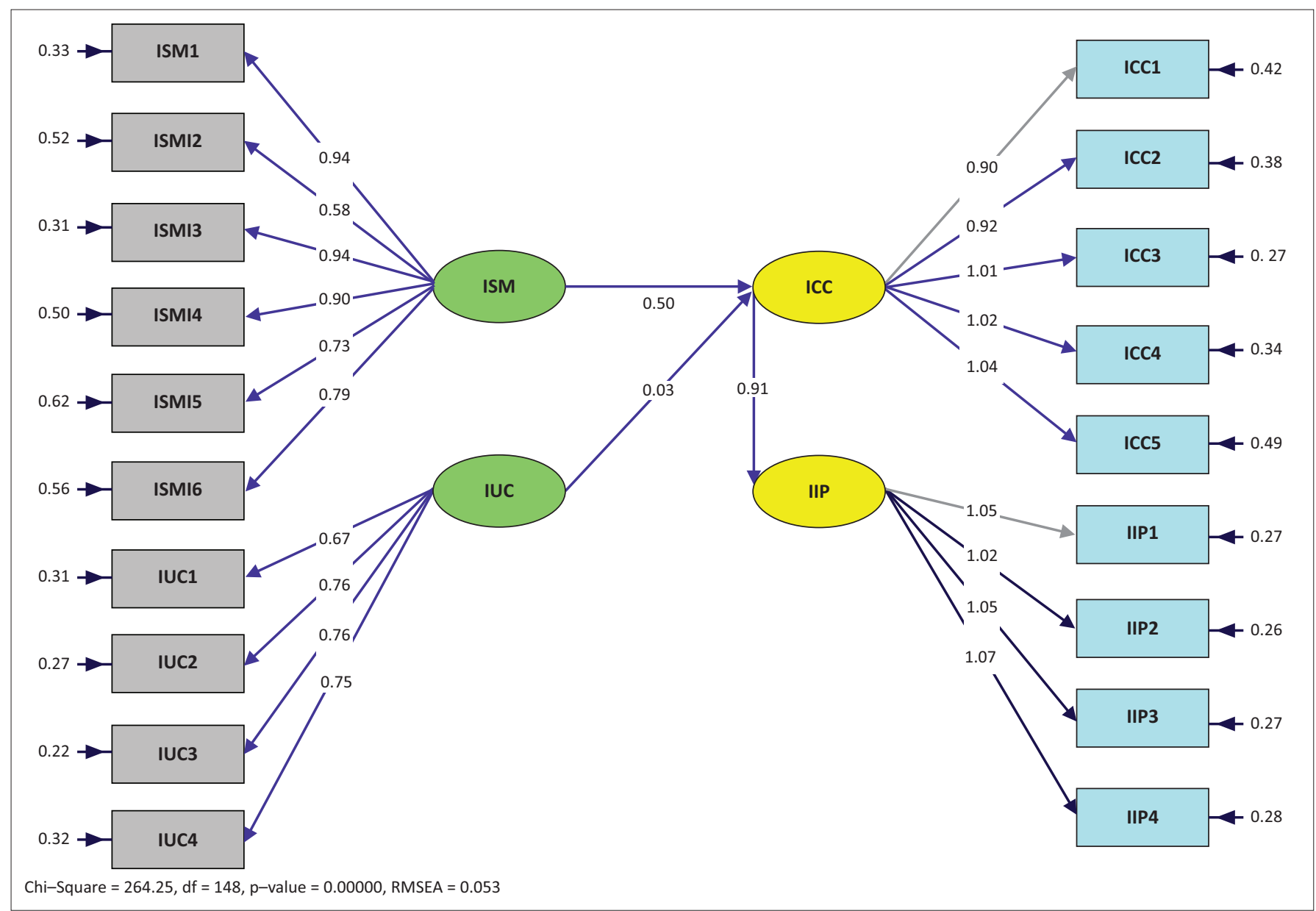

ISM, Instagram social media usage intensity; IUC, Instagram eWOM Credibility; IIP, Instagram Intention to Purchase; ICC, Instagram Conspicuous Consumption; RMSEA, root mean square error of approximation.

FIGURE 2: Structural model.

TABLE 4: Relationship between Instagram conspicuous consumptive behaviour and intention to purchase luxury goods.

\begin{tabular}{lcccc}
\hline Hypothesis & $\begin{array}{c}\text { Path } \\
\text { coefficients }\end{array}$ & $t$ & $p$ & $\begin{array}{c}\text { Reject } \\
\text { hypotheses }\end{array}$ \\
\hline $\begin{array}{l}\text { H1: Instagram usage intensity has a } \\
\text { significantly positive influence on } \\
\text { conspicuous consumptive behaviour. }\end{array}$ & 0.495 & 7.261 & 0.0001 & No \\
$\begin{array}{l}\text { H2: Instagram eWOM credibility has } \\
\begin{array}{l}\text { a significantly positive influence on } \\
\text { conspicuous consumptive behaviour. }\end{array}\end{array}$ & 0.025 & 0.408 & 0.683 & Yes \\
$\begin{array}{l}\text { H3: Instagram conspicuous } \\
\begin{array}{l}\text { consumptive behaviour has a } \\
\text { significantly positive influence on } \\
\text { intention to purchase luxury goods. }\end{array}\end{array}$ & 0.906 & 16.173 & 0.0001 & No \\
\hline
\end{tabular}

eWOM, electronic-word-of-mouth.

purchase luxury goods. The degree of association between variables was depicted by $t$-values and path coefficient values, and these values are shown in Table 4 .

The results of the study proved that Instagram usage intensity significantly influenced conspicuous consumptive behaviour $(t<7.261 ; p<0.0001)$. Users who spend more hours on Instagram daily are more likely to be influenced into conspicuous consumptive behaviours. Conversely, eWOM credibility indicated no influence on conspicuous consumptive behaviour. Electronic-word-ofmouth credibility does not significantly influence conspicuous consumptive behaviour. User do not trust, believe or regard their interactions on Instagram as factual. This inconsequential result is evident from a reported $t$-value score of 0.408 and a $p$-value of 0.683 , which is over the accepted significance level of a $p$-value of 0.05. Of all the factors examined in this study, Instagram conspicuous consumptive behaviour had the greatest influence on intention to purchase luxury goods. This influence is evident in the study results that reported a $t$-value score of 16.173 and a $p$-value of 0.0001 , which is within the generally accepted significance level of a $p$-value of 0.05 .

\section{Assessment of hypotheses}

In order to achieve the research objectives, an assessment of the hypotheses was undertaken to examine the model proposed by the study. A path coefficient range between -1 and +1 , with a $p$-value of 0.05 , was deemed a significant path coefficient score and accepted in this study. Table 4 summarises the assessment of the hypotheses.

\section{Discussion}

The influence of Instagram conspicuous consumptive behaviour on purchase intentions has rarely been researched. However, consumers' social media usage and eWOM's influence on conspicuous consumption have been studied 
(Taylor \& Strutton 2016; Thoumrungroje 2014). This study aimed to explain the determinates of Instagram conspicuous consumptive behaviour and how that behaviour influences their intention to purchase luxury goods using the proposed model. Instagram provides an effective platform for consumers to build personal networks and express themselves. Social media has enabled digitally empowered consumers to share information about products or brands and consequently influence their purchase decisions (Ismail et al. 2018).

\section{Instagram usage intensity}

Results from the structural equation model revealed that Instagram usage intensity significantly influences consumers' conspicuous consumptive behaviour. This finding is in line with similar previous research studies that revealed the same findings (Taylor \& Strutton 2016; Thoumrungroje 2018). The more frequent consumers use Instagram the more likely it will influence their desire to display the social status or wealth. The Instagram usage intensity dimension was the highest in terms of influencing conspicuous consumptive behaviour, with a path coefficient of 0.495 . This could be as a result of the growing dependency on Instagram (Sheldon \& Bryant 2016). Users spend more time on Instagram in an effort to stay up to date with their desired social status. The ability for users to see content from people outside their immediate network allows consumers to view, engage and idealise conspicuous content.

\section{Instagram electronic-word-of-mouth credibility}

The study aimed to test Instagram user credibility against conspicuous consumptive behaviour. Results revealed that Instagram eWOM credibility does not significantly influence conspicuous consumptive behaviour. This is in contrast to the results found by Thoumrungroje (2014). The eWOM credibility has the least influence on conspicuous consumption as opposed to usage intensity. A possibility for this result is that users on Instagram tend to engage without accounts in a social status to which they wish to belong. This mimics Veblen's (1989) conspicuous consumption theory that states that individuals want to identify with the social group directly above them.

Although users on Instagram do not necessarily allow other users on Instagram to influence their conspicuous consumptive behaviour, there is still a high usage. It is possible that users feel that content on Instagram is fabricated. This is corroborated by numerous studies, stating that individuals tend to display the consumption of conspicuous goods as they present favourable images and prestige, which gives positive feedback to other users (Bahtar \& Muda 2016; Duan \& Dholakia 2017; Thoumrungroje 2014). This deliberate display of positive aspects of one's life is a possible reason eWOM on Instagram does not influence conspicuous consumptive behaviour.

\section{Conspicuous consumption and intention to purchase luxury goods}

Empirical research from this study revealed that consumers who exhibit conspicuous consumptive behaviour are likely to turn it into purchase behaviour (Chu et al. 2016; Ismail et al. 2018). The study found a positive significant correlation between Instagram conspicuous consumptive behaviour and intention to purchase luxury goods. This dimension was the highest of the study in its entirety. Users on Instagram display high levels of conspicuous behaviour that they intend to act on in an effort to display their social hierarchy or attain a higher social status. The results of this dimension further contribute to the primary goal of this study, social media conspicuous consumptive behaviour facilitated by Instagram on intention to purchase luxury goods.

\section{Implications and recommendations}

This study contributed to the theoretical and empirical body of knowledge in both the fields of Business Management, Marketing Management and the Luxury goods industry. The results of the study confirm and extend both social media and consumer behaviour literature by empirically presenting the influence of social media on consumers' decisions. The study bridged the existing knowledge gap in current literature by simultaneously considering the usage intensity of social media and the user eWOM credibility present online on conspicuous behaviour. This is important as social media has become a dominant phenomenon in both research and business alike.

Contributing to consumer psychology, the study aimed to understand the influence of eWOM on consumer behaviour by considering factors such as usage, credibility, trustworthiness and factuality of users. In addition, through examining a dominant social media platform, namely Instagram, the study introduced an additional element of behavioural intentions: willingness to act on information provided on Instagram. The study further explained the interconnected dimensions of conspicuous behaviour on intention to purchase.

Findings from this study provide several implications from a managerial perspective, particularly with respect to positioning and message strategies in the social media environment. Social media has effectively changed marketing and the way businesses conduct themselves online (Berthon et al. 2009). The marketer's role has transformed from a broadcaster, whose role is to push a message, to an aggregator who brings the content and enables participation in online communities (Hsu et al. 2016; Tuten \& Solomon 2017). Relationships between brands and consumers are essential and precipitated by consumers' constant information sharing amongst one another.

Therefore, it is recommended that businesses need to be more purposeful in developing social media strategies 
that take consumers' need for conspicuousness into consideration. Brands have a better opportunity to achieve more effective and consistent results if they appeal to a consumer drive to be viewed in a certain manner. Consistent with luxury consumption, emphasis should be placed on tenets of conspicuous consumption such as quality, exclusivity and popularity. Luxury brands should consider using celebrity and social media influencers as the benchmark in online luxury trendsetting. Posting influencers in their products and using Instagram's integrated promotion boosting tools to maximise reach can consequently appeal to the need for consumers to emulate celebrities.

Recent decades have witnessed the great penetration of global brands into emerging markets and such a trend calls for more focused branding strategies, adapting to consumer needs of different segments in emerging markets (Huang \& Wang 2018). South Africa is seen to be no different. High demand for luxury has been observed in both urban and rural regions of South Africa. While this phenomenon can be attributed to growth in numbers of middle-class consumers in emerging markets, the larger population of underprivileged consumers should not be ignored.

\section{Conclusion and suggestions for further research}

In conclusion, the results from the present study can conclude that Instagram is largely influential on a consumer's conspicuous consumptive behaviour which is in line with current literature on the topic. The main contribution to the literature is how marketers view the value of social media marketing as the influence to purchase luxury goods does not stem from eWOM as consumer do not deem each other reliable but stems rather from the dependency and usage intensity of social media. Furthermore, the study revealed that consumers on Instagram have conspicuous behaviours that positively influence their intention to purchase luxury goods, with Instagram being the most influential. As a result of these findings, luxury brand marketers and advertisers are recommended to encourage consumers to give feedback about the products or services of the brand in an effort to identify luxury consumption trends.

However, this study did hold its limitations in that it only focused on Instagram. The research study does not include other social media platforms such as YouTube, Twitter, Facebook and Tumblr, which also have a significant presence in South Africa. Future research might attempt to conduct a survey on other social media platforms, as this would develop a theoretical rationale to better understand social media conspicuous consumptive behaviour on intention to purchase luxury goods.

\section{Acknowledgements Competing interests}

The authors declare that they have no financial or personal relationships that may have inappropriately influenced them in the writing of this research article.

\section{Authors' contributions}

N.M., K.V. and L.C. contributed equally to this research article.

\section{Funding information}

The study was funded by the National Research Foundation (NRF) and the Department of Science and Technology (DST).

\section{Data availability}

Data sharing is not applicable to this article as no new data were created or analysed in this study.

\section{Disclaimer}

The views and opinions expressed in this article are those of the authors and do not necessarily reflect the official policy or position of any affiliated agency of the authors.

\section{References}

Alves, H., Fernades, C. \& Raposo, M., 2016, 'Social media marketing: A literature review and implications', Psychology \& Marketing 33(12), 1029-1038. https://doi. org/10.1002/mar.20936

Bahtar, A.Z. \& Muda, M., 2016, 'The impact of user - Generated content (UGC) on product reviews towards online purchasing - A conceptual framework', Procedia Economics and Finance 37, 337-342. https://doi.org/10.1016/S22125671(16)30134-4

Berthon, P., Pitt, L., Parent, M. \& Berthon, J., 2009, 'Aesthetics and ephemerality: Observing and preserving the luxury brand', California Management Review 51(1), 45-66.

Bongazana, H., 2014, 'Social influence as a determinant of conspicuous consumption among the South African urban township youth', Acta Eniversitatis Danubius 6(2), 59-70.

Chang, C.C. \& Chin, Y.C., 2010, 'The impact of recommendation sources on online purchase intentions: The moderating effects of gender and perceived risk', World Academy of Science, Engineering and Technology 66, 111-114.

Cheung, C.M. \& Thadani, D.R., 2012, 'The impact of electronic word-of-mouth communication: A literature analysis and integrative model', Decision Support Systems 54(1), 461-470. https://doi.org/10.1016/j.dss.2012.06.008

Chu, S., Windels, K. \& Kamal, S., 2016, 'The influence of self-construal and materialism on social media intensity: A study of China and the United States', International Journal of Advertising 35(3), 596-588. https://doi.org/10.1080/02650487.2015.1068425

Chung, E. \& Fischer, E., 2001, 'When conspicuous consumption becomes inconspicuous: The case of the migrant Hong Kong consumers', Journal of Consumer Marketing 18(6), 474-88. https://doi.org/10.1108/07363760110404378

Deghani, M. \& Tumer, M., 2015, 'A research on effectiveness of Facebook advertising in enhancing purchase intention of consumers', Computers in Human Behavior 49, 597-600. https://doi.org/10.1016/j.chb.2015.03.051

Djafarova, E. \& Rushworth, C., 2017, 'Exploring the credibility of online celebrities' Instagram profiles in influencing the purchase decision of young female users', Computers in Human Behvaior 68, 1-7. https://doi.org/10.1016/j.chb.2016.11.009

Duan, J. \& Dholakia, R.R., 2017, 'Posting purchases on social media increases happiness: The mediating roles of purchases' impact on self and interpersonal relationships', Journal of Consumer Marketing 34(5), 404-413. https://doi. org/10.1108/JCM-07-2016-1871

Ellison, N.B., Steinfield, C. \& Lampe, C., 2007, 'The benefits of Facebook friends: Social capital and college students' use of online social networks sites', Journal of Computer-Mediated Communication 12(4), 1143-1168. https://doi.org/10.1111/ j.1083-6101.2007.00367.x

Erkan, I. \& Evans, C., 2016, 'The influence of eWOM in social media on consumers' purchase intentions: An extended approach to information adoption', Computers in Human Behavior 61, 47-55. https://doi.org/10.1016/j.chb.2016.03.003

Faraj, S. \& Johnson, S.L., 2011, 'Network exchange patterns in online communities', Organization Science 22(6), 1464-1480. https://doi.org/10.1287/orsc.1100.0600 
Gao, F. \& Feng, C., 2016, 'Branding with social media: Users gratifications, usage patterns, and brand message content strategies', Computers in Human Behavior 63, 8668-8890. https://doi.org/10.1016/j.chb.2016.06.022

Hammerl, M., \& Kradischnig, C., 2018, 'Conspicuous consumption', in T.K.-S Shackelford (ed.), Encyclopedia of evolutionary psychological science, pp. 1-4, Springer Nature, Austria.

Ho, H., Shin, W. \& Lwin, M.O., 2017, 'Social networking site use and materialistic values among youth', Communication Research 46(8), 1119-1144. https://doi. org/10.1177/0093650216683775

Homans, G.C., 1961, Social behaviour: Its elementary forms, Routledge, London.

Hsu, L., Chih, W. \& Liou, D., 2016, 'Investigating community members' eWOM effects in Facebook fan page', Industrial Management \& Data Systems 116(5), 978-1004. https://doi.org/10.1108/IMDS-07-2015-0313

Huang, Z. \& Wang, C.L., 2018, 'Conspicuous consumption in emerging market: The case of Chinese migrant workers', Journal of Business Research 86, 366-373. https://doi.org/10.1016/j.jbusres.2017.08.010

Hung, K., Chen, A.H., Peng, N., Hackely, C., Tiwaskul, R.A. \& Chou, C., 2011 'Antecedents of luxury brand purchase intention', Journal of Product \& Brand Management 20(6), 457-467. https://doi.org/10.1108/10610421111166603

Ismail, A.R., Nguyen, B. \& Melewar, T.C., 2018, 'Impact of perceived social media marketing activities on brand value consciousness: Roles of usage, materialism and conspicuous consumption', International Journal of Marketing and Advertisin 12(3), 233-254. https://doi.org/10.1504/IJIMA.2018.093387

Jain, S., Khan, M.N. \& Mishra, S., 2015, 'Factors affecting luxury purchase intention: A conceptual framework based on an extension of the theory of planned behaviour' South Asian Journal of Management 22(4), 136-163. https://doi.org/10.1108/ JABS-08-2015-0118

Kaplan, A.M. \& Haenlein, M., 2010, 'Users of the world, unite! The challenges and opportunities of Social Media', Business Horizons 25(6), 59-68. https://doi. org/10.1016/j.bushor.2009.09.003

Kudeshia, C. \& Kumar, A., 2017, 'Social eWOM: Does it affect the brand attitude and purchase intention of brands?', Management Research Review 40(3), 310-330. https://doi.org/10.1108/MRR-07-2015-0161

Li, G., Park, E.M. \& Park, S.T., 2016, 'Effects of social media usage on country image and purchase intention from social P2P network perspective', Peer-to- Peer Networking and Applications 9(3), 487-497. https://doi.org/10.1007/s12083-015-0379-2

Malhotra, N.K., 2014, Basic marketing research, Pearson Education, Upper Saddle River, NJ.

Patricios, O. \& Goldstuck, A., 2018, SA social media landscape 2018, World Wide Worx, Johannesburg.

Pornpitakpan, C., 2004, 'The persuasiveness of source credibility: A critical review of five decades evidence', Journal of Applied Social Psychology 34(2), 243-281. https://doi.org/10.1111/j.1559-1816.2004.tb02547.x
Schiffman, L.G. \& Wisenblit, J., 2015, Consumer behavior, 11th edn., Pearson, London.

Sheldon, P. \& Bryant, K., 2016, 'Instagram: Motives for its use and relationship to narcissism and contextual age', Computers in Human Behavior 58, 89-97. https:// doi.org/10.1016/j.chb.2015.12.059

Sher, P.J. \& Lee, S.H., 2009, 'Consumer skepticism and online reviews: An elaboration likelihood model perspective', Social Behavior and Personality 37(1), 137-143. https://doi.org/10.2224/sbp.2009.37.1.137

Smith, R.E. \& Vogt, C.A., 1995, 'The effects of integrating advertising and negative word-ofmouth communications on message processing and response', Journal of Consumer Psychology 4(2), 133-151. https://doi.org/10.1207/s15327663jcp0402_03

Surma, J., 2015, 'Social exchange in online social networks: The reciprocity phenomenon on Facebook', Computer Communications 73(Part B), 342-346. https://doi.org/10.1016/j.comcom.2015.06.017

Sussman, S.W. \& Siegal, W.S., 2003, 'Informational influence in organizations: An integrated approach to knowledge adoption', Information Systems Research 14(1), 47-65. https://doi.org/10.1287/isre.14.1.47.14767

Taylor, D. \& Strutton, D., 2016, 'Does Facebook usage lead to conspicuous consumption?', Journal of Research and Interactive Marketing 10(3), 231-248. https://doi.org/10.1108/JRIM-01-2015-0009

Thoumrungroje, A., 2014, 'The influence of social media intensity and eWOM on conspicuous consumption', Procedia - Social and Behavioral Science 148, 7-15. https://doi.org/10.1016/j.sbspro.2014.07.009

Thoumrungroje, A., 2018, 'A cross-national study of consumer spending behavior: The impact of social media intensity and materialism', Journal of International Consumer Marketing 30(4), 276-286. https://doi.org/10.1080/08961530.2018.1 462130

Tien, D.H., Rivas, A. \& Liao, Y., 2018, 'Examining the influence of customer-tocustomer electronic purchase intention in social networking sites', Asia Pacific Management Review 24(3), 238-249. https://doi.org/10.1016/j. apmrv.2018.06.003

Tuten, T.L. \& Solomon, M.R., 2017, Social media marketing, Sage, London.

Veblen, T., 1899, The theory of the leisure class: An economic study in the evolution of institutions, Macmillan, London.

Wiid, J. \& Diggines, C., 2015, Marketing research, 3rd edn., Juta and Company, Cape Town.

Wilcox, K. \& Stephen, A.T., 2013, 'Are close friends the enemy? Online social networks, self-esteem, and self-control', Journal of Consumer Research 40(1), 90-103. https://doi.org/10.1086/668794

Yenicioglu, B. \& Christodoulides, G., 2014, Branding in the age of digital connectivity, Routledge, London. 